\title{
Factors Affecting the Success of Smoking Cessation Clinic: A Cross-Sectional Study
}

\author{
Sigara Bırakma Polikliniğinin Başarısını Etkileyen Faktörler: Kesitsel Bir Çalışma
}

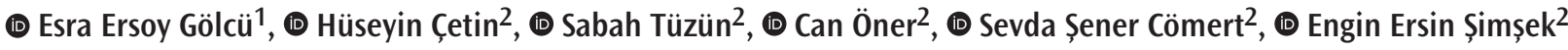 \\ ${ }^{1}$ Kuruköprü State Hospital, Istanbul, Turkey \\ 2istanbul Kartal Dr. Lütfi Kırdar Training and Research Hospital, İstanbul, Turkey
}

\section{Abstract}

Objective: This study aimed to determine the frequency of smoking cessation and affecting factors in patients who applied to the smoking cessation clinic.

Method: This study included smokers aged 18 years and over who applied to the Chest Diseases Clinic Smoking Cessation Outpatient Clinic between 1 April 2019 and 31 July 2019. All participants were evaluated with a sociodemographic questionnaire, Fagerström Test for Nicotine Dependence (FNBT) and Beck Depression Scale during the initial outpatient clinic admission. Subsequently, smoking cessation treatment was started and all participants were called at 6 and 12 months and their smoking cessation status was questioned. Smokers who did never smoked for the last 1 year were accepted as ex-smokers.

Results: A total of 270 participants were included in the study, and 48 (19.5\%) of the participants were found to quit smoking at the end of one year. There was no significant difference between ex-smokers and current smokers in terms of age, gender, marital status, educational level, employment status, income level, duration of smoking, FNDT and Beck's depression scores. However, smoking status in the phone call at 6-month was found to be an important factor affecting the success of smoking cessation at 12 months.

Conclusion: Although the success rate for individuals who want to quit smoking is quite low in the literature, accessing appropriate pharmacological treatment may increase the success of smoking cessation. Additionally, it has been observed that ex-smokers quit smoking, especially in the first 6 months.

Keywords: Smoking cessation, nicotine dependence, varenicline, tobacco use cessation products

\section{Öz}

Amaç: Bu çalışmada sigara bırakma polikliniğine bașvuran hastalarda sigara bırakma sıklığı ve etkili faktörlerin belirlenmesi amaçlanmıștır.

Yöntem: Bu çalışmaya 1 Nisan 2019 -31 Temmuz 2019 tarihleri arasında Göğüs Hastalıkları Kliniği Sigara Bırakma Polikliniğine başvuran 18 yaş ve üzeri, sigara kullanan bireyler dahil edilmiștir. Tüm katılımcılar ilk poliklinik bașvurusu esnasında sosyodemografik anket, Fagerström Nikotin Bağımlılık Testi (FNBT) ve Beck Depresyon ölçeği ile değerlendirilmiștir. Ardından, tüm katılımcılara sigara bırakma tedavisi bașlanmış ve 6 ve 12 .ayda telefon ile aranarak, sigara bırakma durumları sorgulanmıștır. Son 1 yılda hiç sigara içmemiş olanlar sigarayı bırakmış olarak kabul edilmiștir.

Bulgular: Çalıșmaya toplam 270 katılımcı dahil edilmiș ve katılımcıların 48 (\%19.5)'i bir yıl sonunda sigarayı bıraktığı saptanmıștır. Sigarayı bırakan ve bırakmayan bireyler arasında yaş, cinsiyet, medeni durum, eğitim düzeyi, çalıșma durumu, gelir düzeyi, sigara kullanım süresi, FNBT ve Beck Depresyon puanları açısından anlamlı fark gözlenmemiştir. Bununla beraber, 6.aydaki telefon aramasında sigara içme durumunun 12.ayda sigara bırakma başarısını etkileyen önemli bir faktör olduğu saptanmıştır.

Sonuç: Sigara bırakmayı talep eden bireylerde başarı oranı literatürde oldukça düşük olmakla beraber, uygun farmakolojik tedaviye ulaşılmasının sigara bırakma başarısında artış sağlayabilir. Ayrıca, sigarayı bırakanların özellikle ilk 6 ayda sigarayı bıraktığı gözlemlenmiştir.

Anahtar kelimeler: Sigarayı bırakma, Nikotin bağımlıı̆̆ı, Vareniklin, Sigara bıraktırma ürünleri 


\section{Introduction}

Smoking is defined as the most important preventable health issue by the World Health Organization (1). Smoking, which is among the leading causes of preventable mortality and morbidity, causes 1 out of 5 deaths (2-4). Tobacco use is a risk factor for cancer, cardiovascular disease, lung diseases, respiratory tract and other infections, osteoporosis, reproductive disorders, postoperative adverse events and delayed wound healing, duodenal and stomach ulcers (3). The nicotine substance found in the tobacco plant causes a high degree of dependence by acting on the nicotinic cholinergic receptors in the brain to trigger the release of dopamine and other neurotransmitters (3).

The smoking prevalence varies between 10.0-29.9\% all over the world in 2015 (5). Although a significant proportion of individuals who smoke are not satisfied with being a smoker, they continue their smoking behavior due to nicotine addiction (3). Studies have shown that $53-70 \%$ of individuals who smoke want to quit smoking and $40 \%$ quit for at least 1 day each year $(3,4)$. Moreover, $80 \%$ of those who try to quit smoking on their own within a month and only $3 \%$ of those who smoke each year successfully quit smoking (3). However, nicotine addiction is the most important reason for maintaining smoking behavior and general failure of treatment attempts (3). On the other hand, only about $30 \%$ of the world population can access appropriate tobacco cessation support due to low tobacco cessation support worldwide (6). There are behavioural counseling and medical treatment methods proven to be effective in smoking cessation (1). The most commonly used medical treatments for smoking cessation are varenicline, bupropion, and nicotine replacement therapy (NRT) $(1,4)$. The success rate for individuals who try to quit smoking alone is very low with 3-7.5\% (2,4). However, the success of smoking cessation increases up to $14.6-45.5 \%$ with medical treatments (1). Our study includes the frequency of smoking cessation in our smoking cessation outpatient clinic and the factors that may be effective. Assessment of the factors affecting the success of smoking cessation may provide a review of the issues that should be considered in the success of treatment. This study aimed to determine the frequency of smoking cessation and effective factors in patients who presented to the smoking cessation outpatient clinic.

\section{Methods}

\section{Sample}

This cross-sectional study included smokers aged 18 years and over who presented to the Chest Diseases Clinic Smoking Cessation Outpatient Clinic of Kartal Dr Lutfi Kırdar City Hospital between 1 April 2019 and 31 July 2019. All participants were called at 6 and 12 months and their smoking cessation status was evaluated. Smokers who did never smoked for the last 1 year were accepted as ex-smokers and smokers who still continue to smoke were accepted as current smokers. Two hundred seventythree participants applied to the outpatient clinic during 4 months. Three (1.1\%) patients could not be reached by phone in 6 months. Patients who could not be reached by phone call at 6 months were excluded from the study.

The sample size was calculated using the prevalence of $19.3 \%$, margin error of $5 \%$, confidence level of $95 \%$, and missing data of $10 \%$ (1). The target sample size was determined as 263 patients and the target sample size was reached.

\section{Procedure}

The study was approved by the Ethics Committee of Kartal Dr Lutfi Kırdar Training and Research Hospital (Approval date: March 27, 2019 and approval number: 2019/514/150/13). A sociodemographic form, Fagerström Nicotine Dependence Test (FNDT) and Beck Depression Scale were administered to all participants during the initial outpatient clinic admission. In addition, the measurement of carbon monoxide (CO) level was evaluated in the expiratory air of all participants. Subsequently, while a structured motivational interview was applied to all participants, pharmacological treatment was also applied to the appropriate participants. A questionnaire form consisting of 31 questions prepared by the researchers to evaluate sociodemographic characteristics and smoking status, Fagerström Nicotine Dependence Test (FNDT) and Beck Depression Scale were administered to all participants by the same researcher.

\section{Measures}

\section{Fagerström Nicotine Dependence Test (FNDT)}

FNDT is a self-report scale that shows nicotine addiction levels $(8,9)$. In FNDT consisting of a total of 6 items, a total score of $0-2$ points is classified as very low, 3-4 points low, 5 point moderate, 6-7 points high, and 8-10 points very high dependence (8). The Turkish validity and reliability study of FNDT was conducted by Uysal et al. and the reliability value (Cronbach Alpha) was found to be $0.56(9)$.

\section{Beck Depression Scale}

Additionally, Beck Depression Scale, applied to all participants and used to measure the risk and severity of depression (10). The total score that can be obtained from the scale is between 0 and 63 (10). The cut-off value of the scale was determined as 17 points and its Cronbach alpha value was found to be 0.80 (10).

\section{Statistical Analysis}

SPSS version 23.0 software was used to analyze the data. Frequency, percentage, mean, standard deviation, median 
and interquartile range were used in the descriptive statistical analysis of the data. The student's t-test was used for the analysis of normally distributed continuous variables (age and FNDT score) between current and ex-smoker groups, while the Mann-Whitney $U$ test was used for the analysis of nonnormally distributed continuous variables (duration of cigarette consumption, co level, Beck depression score) between current and ex-smoker groups. The Chi-square test was used for the analysis of categorical data (gender, mariatel status, educational status, employment status, monthly income, living together, smoking status at 6 months, smoking starting age, use of other tobacco products, smoking at home, smoking in the workplace, treatment administered, side effects of treatment) between current and ex-smoker groups. In addition, when the variables affecting the success of smoking cessation were evaluated, logistic regression analysis was performed for the variables that were found to be significant and the first category was accepted as the reference category for all variables. A p-value of less than 0.05 was considered significant in all analysis results.

\section{Results}

The study included a total of 270 participants, 48 (19.5\%) of participants was ex-smoker at the end of one year. Sociodemographic characteristics of ex-smoker and current smoker groups are summarized in Table 1.

The age of starting smoking for all participants was $17.9 \pm 5.1$ years and the duration of cigarette consumption was 20.0[20.0] packs/year. The smoking characteristics of ex-smoker and current smoker groups are summarized in Table 2.

When the smoking cessation status of the participants was evaluated according to the treatment protocols, a significant difference was found between those who received NRT with motivational interviewing and those who received varenicline with motivational interviewing treatment $(p=0.028)$.

It was found that $49(19.9 \%)$ of participants quit smoking at the end of 6 months. The factors affecting smoking cessation success at the end of a year are summarized in Table 3 (-2 Loglikelihood $=81.747$, Nagelkerge R2 $=0.766, p<0.001$ ).

Table 1 Sociodemographic characteristics of ex-smoker and current smoker groups

\begin{tabular}{|c|c|c|c|}
\hline & $\begin{array}{l}\text { Ex-smoker } \\
(\mathrm{n}=48)\end{array}$ & Current smoker $(n=196)$ & p \\
\hline Age (years) & $42.7 \pm 12.0$ & $40.5 \pm 11.5$ & 0.275 \\
\hline $\begin{array}{l}\text { Gender } \\
\text { Female } \\
\text { Male }\end{array}$ & $\begin{array}{l}21(43.8) \\
27(56.3)\end{array}$ & $\begin{array}{l}98(49.5) \\
100(50.5)\end{array}$ & 0.522 \\
\hline $\begin{array}{l}\text { Marital status } \\
\text { Married } \\
\text { Single } \\
\text { Widowed/divorced }\end{array}$ & $\begin{array}{l}31(64.6) \\
15(31.3) \\
2(4.2)\end{array}$ & $\begin{array}{l}127(64.1) \\
45(22.7) \\
26(13.1)\end{array}$ & 0.144 \\
\hline $\begin{array}{l}\text { Educational status } \\
\text { Below High School } \\
\text { High Scool and Above }\end{array}$ & $\begin{array}{l}17(35.4) \\
31(64.6)\end{array}$ & $\begin{array}{l}87(43.9) \\
111(56.1)\end{array}$ & 0.330 \\
\hline $\begin{array}{l}\text { Employment status } \\
\text { Unemployed or retired } \\
\text { Government } \\
\text { Private sector } \\
\text { Own business }\end{array}$ & $\begin{array}{l}19(40.4) \\
5(10.6) \\
20(42.6) \\
3(6.4)\end{array}$ & $\begin{array}{l}77(39.7) \\
20(10.3) \\
85(43.8) \\
12(6.2)\end{array}$ & 0.999 \\
\hline $\begin{array}{l}\text { Monthly income } \\
\text { Less than minimum wage } \\
\text { Two times the minimum wage } \\
\text { Three times the minimum wage }\end{array}$ & $\begin{array}{l}5(10.6) \\
36(76.6) \\
6(12.8)\end{array}$ & $\begin{array}{l}42(21.3) \\
143(72.6) \\
12(6.1)\end{array}$ & 0.099 \\
\hline $\begin{array}{l}\text { Living together } \\
\text { Absent } \\
\text { Present }\end{array}$ & $\begin{array}{l}5(10.4) \\
43(89.6)\end{array}$ & $\begin{array}{l}16(8.1) \\
182(91.9)\end{array}$ & 0.572 \\
\hline
\end{tabular}


Table 2. The smoking characteristics of ex-smoker and current smoker groups

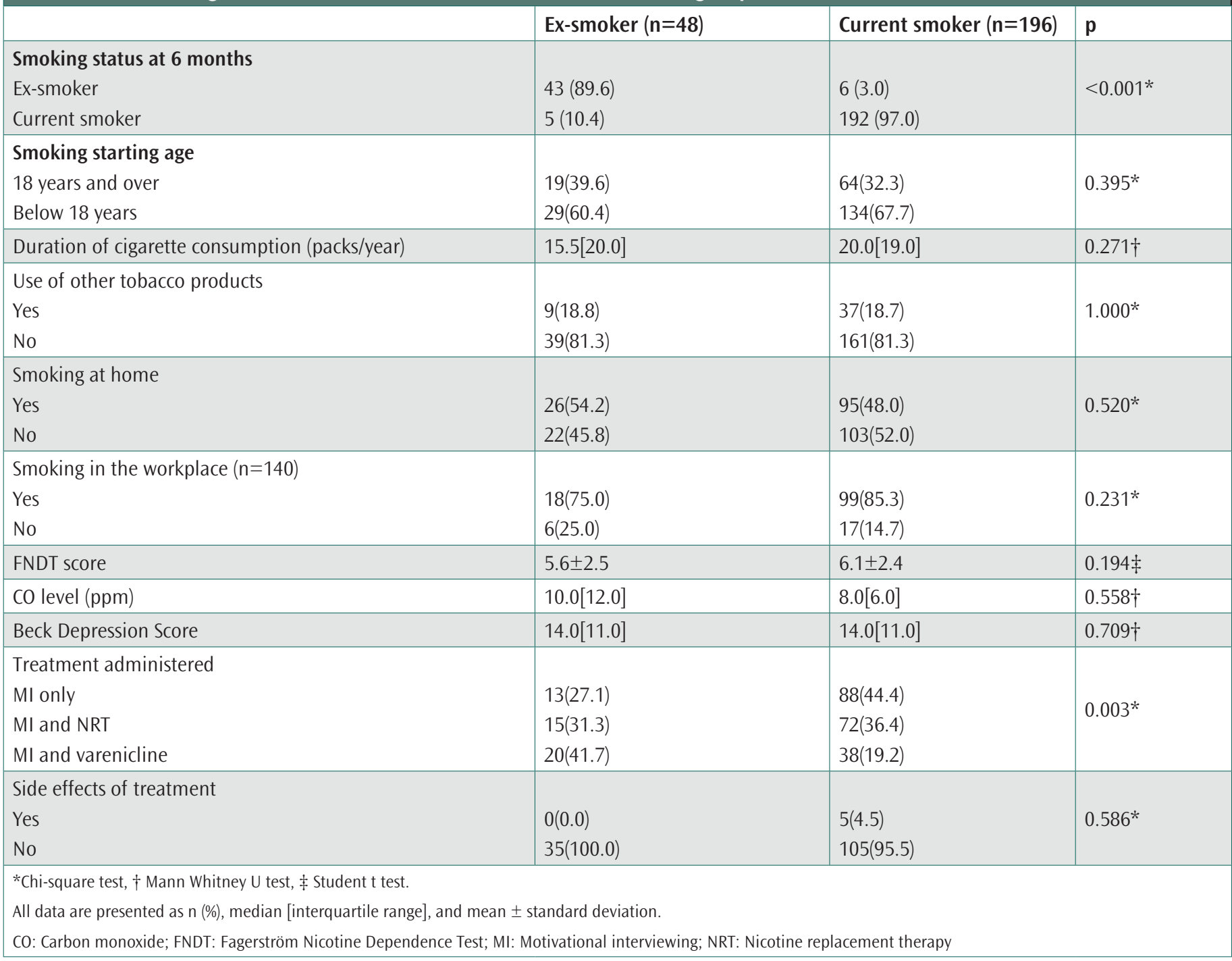

Table 3: Factors affecting smoking cessation success at the end of a year

\begin{tabular}{|c|c|c|c|c|c|c|c|}
\hline \multirow{2}{*}{ Variables } & \multirow{2}{*}{ B } & \multirow{2}{*}{$\begin{array}{l}\text { Standard } \\
\text { error }\end{array}$} & \multirow{2}{*}{ Wald } & \multirow{2}{*}{$p$} & \multirow{2}{*}{$\operatorname{Exp}(B)$} & \multicolumn{2}{|l|}{$95 \% \mathrm{Cl}$} \\
\hline & & & & & & Low & High \\
\hline \multicolumn{8}{|l|}{ Treatment } \\
\hline $\mathrm{MI}+$ Varenicline & 0.146 & 0.838 & 0.030 & 0.862 & 1.157 & 0.224 & 5.983 \\
\hline Constant & 0.836 & 0.318 & 6.904 & 0.009 & 2.306 & & \\
\hline
\end{tabular}




\section{Discussion}

This study aimed to determine the frequency of smoking cessation and effective factors in patients who applied to the smoking cessation outpatient clinic. In our study, the smoking cessation rate of participants at the end of one year was $19.5 \%$. The use of varenicline treatment with the motivational interview was found to be higher among ex-smokers compared to other treatment protocols. In addition, the evaluation of the factors affecting smoking cessation success in this study showed that quitting smoking at 6 months were significant factors.

Studies have a smoking cessation rate ranging between 10.9$40.4 \%$ at 12 months and between $15.8 \%$ to $51.7 \%$ at 6 months $(11,12)$. In our study, the smoking cessation rate was found to be $19.5 \%$ at 12 months and $19.9 \%$ at 6 months. The reason for the relatively low rate of smoking cessation in our study compared to other studies may be due to the difficulties in accessing the pharmacological treatment protocols provided by the Ministry of Health free of charge to the individuals at the time of the study.

When smoking cessation and sociodemographic characteristics were evaluated, one study found a high frequency of smoking cessation in men, while other studies have found no difference between gender and smoking cessation status (1,2,12-15). The relationship between the age of individuals and their smoking cessation success is controversial in studies $(1,2,14,15)$. While some studies found that the individual's age did not affect the success of smoking cessation, some studies have found a higher rate of quitting smoking in older individuals (1,2,12-16). Studies have found no difference between marital status and smoking cessation $(14,15)$. However, one study found that a higher rate of divorced individuals were able to quit smoking (2). Two international studies found a lower rate of quitting smoking in individuals with a low socioeconomic level and low educational level $(17,18)$. Other studies have found no difference between smoking cessation status and educational level $(1,2,12,14,15)$. Some studies found no difference between smoking cessation status and working status $(2,12)$. In this study, no difference was observed between smoking cessation and age, gender, marital status, employment status, socioeconomic and educational level.

While one study found that the rate of smoking cessation was higher in long-term smokers, some studies found no difference between the age of starting smoking, the duration of cigarette consumption and the age of quitting smoking $(1,2,12,14,15)$. Some studies found a lower FNDT score in ex-smokers compared to current smokers, while some studies found no similar differences $(1,2,15,16)$. Some studies found a lower rate of smoking in the workplace of ex-smokers, while another study found between ex-smokers and current smokers in terms of smoking in the workplace $(1,2,18)$. While some studies found that the rate of smoking cessation of the smokers was lower when there was a smoker at home, one study found no difference $(1,14,17,18)$. A study found no difference between ex-smokers and current smokers in terms of depression questionnaire scores (15). In our study, no difference was observed between exsmokers and current smokers in terms of age at starting smoking, duration of smoking, FNDT score, smoking at home, smoking in the workplace, FNDT score, CO level and Beck depression score.

While the success rate for individuals who try to quit smoking alone is $3-7.5 \%$, the success rate of quitting smoking with medical treatments increases to $14.6-45.5 \%(1,4)$. The most commonly used medical treatments for smoking cessation are varenicline, bupropion, and NRT $(1,4,15)$. According to the results of two meta-analysis, varenicline, bupropion and NRTs were shown to be superior to placebo in terms of smoking cessation $(18,20)$. The effect of the added pharmacological treatment on the success of smoking cessation was higher than behavioral education $(14,15)$. On the other hand, one study found no difference in smoking cessation between NRT and other pharmacological treatments (2). Another study found no difference between NRT, bupropion, and varenicline treatments and smoking cessation success (1). A meta-analysis study found that varenicline increased the probability of smoking cessation 2.8 times more than placebo (20). Studies comparing varenicline and bupropion have found that varenicline was found to be more effective than bupropion in terms of smoking cessation (19-21). Additionally, one study found a significantly higher smoking cessation success rate in individuals who received varenicline treatment compared to other pharmacotherapy treatment protocols (20). A study by Cahill et al. found that varenicline treatment used for smoking cessation treatment was superior to single NRTs and bupropion (20). In another study, varenicline treatment was observed to be effective when combined with counseling service (14). In this study, there was a significantly higher rate of patients who were initiated on varenicline treatment with a structured motivational interview in the current smoker group.

The limitation of our study is that individuals did not access pharmacological treatments that were deemed appropriate for smoking cessation from time to time during the study period.

In conclusion, smoking is an important public health issue all over the world. It is still among the leading causes of death today (1-4). In our study, the smoking cessation rate was 19.9\% at 6 months and $19.5 \%$ at 12 months. In addition, the smoking cessation rate at 6 months was determined to be the most common factor among the factors affecting smoking cessation success at 12 months. Furthermore, the frequency of varenicline use was observed to be higher in ex-smokers compared to current smokers. However, there no correlation between smoking cessation and gender, marital status, monthly income, 
age at starting smoking, duration of smoking, FNDT score, Beck depression score, and CO level. In conclusion, although the success rate for individuals who want to quit smoking is quite low in the literature, accessing appropriate pharmacological treatment may increase the success of smoking cessation. Additionally, it has been observed that ex-smokers quit smoking, especially in the first 6 months.

\section{References}

1. Kanatsız B, Başılılar \$, ŞaylanB, et al. Evaluation of the factors affecting success rate and medical treatments in smoking cessation. Eurasian Journal of Family Medicine 2017; 6(2): 65-71.

2. Arpacıoğlu S, Ünübol B, Bilici R, Erzincan E. Results of smoking cessation clinic in Erenköy Mental and Neurological Diseases Training and Research Hospital: an investigation into the effects of cognitive behavioral intervention and pharmacotherapy. Addicta: The Turkish Journal on Addictions 2019; 6(4): 295-314.

3. Benowitz Neal L. Nicotine addiction. N Engl J Med 2010; 362(24): 2295-2303.

4. Blak Betina T, Wilson K, Metcalfe M, et al. Evaluation of varenicline as an aid to smoking cessation in UK general practice-a thın database study. Curr Med Res Opin 2010; 26(4): 861-870.

5. World Health Organization. Global Report on Trends in Prevalence on Tobacco Smoking 2000-2025, Second Edition. Geneva: World Health Organization, 2018.

6. World Health Organization. Report On The Global Tobacco Epıdemic. Offer Help To Quit Tobacco Use. Geneva: World Health Organization, 2019.

7. Turkish Ministry of Health. General Directorate of Public Health. https:// hsgm.saglik.gov.tr/tr/bagimliliklamucadele-haberler/sigara-birakmahizmetleri.html. (Accessed date:5/22/2021).

8. Sağlam L. Clinical evaluation of nicotine dependence. Güncel Göğüs Hastalıkları Serisi 2017; 4(1): 78-89.

9. Uysal MA, Kadakal F, Karșıdağ Ç, et al. Fagerstrom test for nicotine dependence:reliability in a Turkish sample and factor analysis. Tüberk Toraks 2004; 52(2): 115-121.
10. Hisli N. Beck Depresyon enventerinin üniversite öğrencileri için geçerlilik ve güvenilirliği. Psikoloji Dergisi 1989; 7(23): 3-13.

11. Benli AR, Erturhan S, Oruc MA, et al. A comparison of the efficacy of varenicline and bupropion and an evaluation of the effect of the medications in the context of the smoking cessation programme. Tob Induc Dis. 2017; 15: 10 .

12. Sağlam L. Investigation of the results of asmoking cessation clinic and the factors associated with success. Turk J Med Sci 2012; 42(3): 515-522.

13. Poulsen PB, Spillemose H, Nielsen $\mathrm{G}$, et al. Real-life effectiveness of smokingcessation treatments in general practice clinics in Denmark. The Escape Smoke project. Respir Med 2015; 109(2): 218-227.

14. Argüder E, Karalezli A, Hezer $\mathrm{H}$, et al. Factors affecting the success of smoking cessation. Turk Toraks Derg 2013; 14(3): 81-87.

15. Yaşar Z, Kar Kurt Ö, Talay F, Kargı A. One-year follow-up results of smoking cessation outpatient clinic: factors a ecting the cessation of smoking. Eurasian J Pulmonol 2014; 16(2): 99-104.

16. Raherison C, Marjary A, Valpromy B, et al. Evaluation of smoking cessation success in adult. Respir Med 2005; 99(10): 1303-1310.

17. Blok DJ, de Vlas SJ, van Empelen P, van Lenthe FJ. The role of smoking in social networks on smoking cessation and relapse among adults: a longitudinal study. Prev Med 2017; 99: 105-110.

18. Janson C, Künzli N, de Marco R, et al. Changes in active and passive smoking in the European Community Respiratory Health Survey. Eur Respir J 2006; 27(3): 517-524.

19. Eisenberg MJ, Filion KB, Yavin D, et al. Pharmacotherapies for smoking cessation: a meta-analysis of randomized controlled trials. CMAJ 2008; 179(2): 135-144.

20. Cahıll K, Stevens S, Perera R, Lancaster T. Pharmacological interventions for smoking cessation: an overview and network meta-analysis. Cochrane Database Syst Rev 2013 (5): CD009329.

21. Hughes JR, Stead LF, Hartmann-Boyce J, et al. Antidepressants for smoking cessation. Cochrane Database Syst Rev 2014 (1): CD000031. 